\title{
COMPULSORY PASTEURIZATION OF MILK
}

\author{
IN DANISH DAIRIES AS A PRECAUTION AGAINST THE \\ SPREAD OF TUBERCULOSIS.
}

BY HARALD FABER, F.C.S.

I.

The introduction of tubereulin as a diagnostic means of demonstrating the infection of cattle by tuberculosis has revolutionized our ideas as to the extension of this disease and also in a certain measure as to its character. Instead of considering it a hereditary disease, we now know it to be purely contagious, contracted by the absorption into the system of bacilli derived from another individual affected by this disease. It has been proved that calves are very seldom born tuberculous even when both parents are tubereulous. If a cow be very highly infected, and especially when the uterus is affected, the calf may or may not contract the disease before birth. It has been found, as the result of many investigations in Denmark and Germany, that although a large proportion of the cattle in these countries are tuberculous (as is also the case in Great Britain and in most civilized countries), only between $\frac{1}{3}$ and $\frac{1}{2}$ per cent. of all calves are born with the disease.

The disease is conveyed, with the bacilli, in many different ways, which, however, can be grouped in two important divisions, viz. (1) by drinking the milk containing the bacilli, and (2) by inhaling dust or other small particles contaminated by the expectoration or discharge of tuberculous matter or by eating food similarly contaminated. It is the first which is mainly responsible for the infection of calves.

In the year May, 1897, to June, 1898, Dr. B. Bang of Copenhagen, to whose excellent investigations and untiring work in combating this disease we owe so much of our present knowledge, had about 66,000 head of cattle tested by the tuberculin test, when he found that 23.8 per cent. reacted; but grouping the animals according to age, he found-

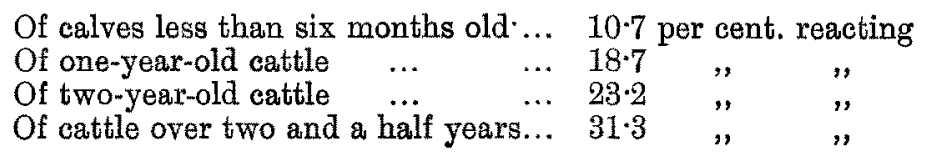

These progressive percentages, which are found invariably every year, and in all countries, are most instructive. They prove the 
contagious nature of the disease. The reacting percentage of calves under six months of age is very instructive as indicating that in that short time more than one out of every ten calves had been infected, even if we take into consideration the fact that from $\frac{1}{3}$ to $\frac{1}{2}$ per cent. may have been born tuberculous. That milk containing the bacilli is the chief source of conveying the contagion to calves is highly probable. While milk from cows suffering from tuberculosis of the udder is the most infectious, that from very badly affected cows may not unfrequently contain the bacilli, although the udder shows no sign of tuberculosis. Dr. Bang communicated to the International Congress of Hygiene in London, 1891, the result of inoculating millk from sixty-three such cows into rabbits and guinea-pigs, when it was found that the milk in nine cases (14 per cent.) caused tuberculosis. The effect of millk from a tuberculous udder was demonstrated by Dr. Bang by the following experiment amongst others. On the 4th of March, 1899, the small dose of forty grams, $\frac{x}{15}$ of a pint, of such milk, was given as food to each of five perfectly healthy calves, three months and a half old, and the same dose was repeated on the 10th of the same month. Three of the five calves were killed, one each day, on 17 th of June, 1st of July, and 24th of November, and examined. They were all highly tuberculous, and increasingly so with the interval since the date of infection. The two remaining calves had not been examined at the time of writing. On the other hand, Dr. Bang fed a calf during several months with milk from a tuberculous udder without producing the slightest trace of tubereulosis, as the milk had been boiled before it was given to the calf. "I wish," he exclaims, " that all breeders of cattle-and all physicians who still permit children to drink raw milk from tuberculous cows-would take cognizance of such experiences."

The use of tuberculin on the one hand caused widespread consternation by disclosing the fact that the herds in most civilized countries, especially where cattle frequently change hands, were attacked to the extent of 20,30 , or even 50 per cent. On the other hand, it helped clearly to prove that the spread of the disease could be checked, and the disease even be gradually eliminated. The way in which this has been practised on many farms in Denmark since 1893 on the lines laid down by Dr. Bang, includes, (1) separating the herd into an infected (reacting) and a healthy division; (2) adding to the herd as far as possible only calves of own breeding; (3) the removal of the calves soon after birth from the infected division, and feeding them from the second day on either boiled milk (or milk heated to $185^{\circ} \mathrm{F}$.) or milk from healthy 
cows; and (4) repeating the testing of the healthy division once or twice a year.

One of the most important points is to avoid inoculating the young calves by means of infected milk, and the milk given them is therefore heated or boiled, whereby all tubercle bacilli are destroyed. It is already possible to point to a distinct improvement arrived at by feeding the calves on boiled milk or mill from healthy cows, and keeping them apart from the infected cows, inasmuch as the percentage of calves under six months found tuberculous by the many thousand tuberculin-tests performed yearly, has decreased from $16^{\circ} 6$ in $1893-94$, and $15^{*} 3$ in 1894-95, to $9 \cdot 7$ in $1898-99$.

There was, however, a very important and serious source of contamination to be reckoned with. Most farmers send their milk to a dairy factory, where it is mixed with milk from many other farms. The mixed separated milk or butter-milk is returned to the farmers and used for feeding calves. If one or more of the farmers supplied milk contaminated with tubercle bacilli, the mixed milk became contaminated, and where the farmers did not boil the milk from the factory, they ran the risk of having their calves infected. It is believed that not a few perfeetly healthy herds have in this way been attacked. (Every fourth of $f_{s}$ the examined herds to the total of over 9,000 have been found perfectly free from tubereulosis.) Most dairy factories have for years been in the habit of heating the separated milk, as otherwise it does not keep sweet long enough, and the temperature to which the separated milk is heated is in most cases high enough to ensure the complete destruction of the tubercle bacilli.

It was evidently very important, if possible, to more effectually eliminate this source of infection. It was not enough that many or most factories heated the separated milk, they ought all to do so; it was not sufficient that they heated it if they did not reach a temperature fatal to the tubercle bacilli; finally, a very considerable gap was. left for the contagion as long as the butter-milk was not equally heated and disinfected. For the purpose of combating tuberculosis in cattle, and at the same time in man, it was highly desirable to require all factories to so heat all the milk, and to compel them by law to do so. But was it reasonable to lay such restrictions on a great industry? Could, indeed, the manufacture of high-class butter be carried on, and economically carried on, when both separated milk and butter-milk were to be heated to such a degree? The development of dairy science gave the desired answer to these questions. 


\section{II.}

In a remarkably short time a new system of treating cream in dairies and factories, previous to churning, has been adopted in Denmark, and has spread thence to other countries, even as far as Australia. The origin of this treatment of cream, viz., pasteurization and the use of a more or less pure cultivation of bacteria to staxt the fermentation necessary for the development of the butter flavour, can be traced to a serious complaint of the quality of the butter made on a certain estate, the property of the present Danish Minister of Agriculture. Careful inspection, both veterinary and dairy-technical, showed that although the animals were healthy and no skill was wanting in the manipulations in the dairy, the butter was nevertheless very unpalatable. As nothing availed to get over this difficulty, on an estate previously renowned for its fine butter, and as the evil spread to neighbouring dairies, the State Laboratory for Agricultural Research at Copenhagen was applied to. A bacteriological laboratory was fitted up on the estate, and it was proved that the milk was pure when milked (with bacteriological precautions); that a certain microbe present in the dairy, the cowsheds and one of the wells was the cause of the disagreeable taste and flavour of the butter; that this microbe was destroyed by heating the milk or the cream to $160^{\circ} \mathrm{F}$.; that cream so heated did not retain a boiled taste when quickly cooled down; and finally, that excellent butter could be made from the cream when the obnoxious microbes had been killed by heating, the cream subsequently cooled and a fermentation-starter added, being either buttermilk from $a_{4}$ dairy producing fine butter or a "pure cultivation."

The absolute success of this attempt to discover and to check the cause of a disease in milk producing bad flavour in butter led to the application of the same method of pasteurization in other dairies, and it was found that it invariably resulted in an improved quality of butter. The pasteurization of cream (in connection with the use of "pure cultivations" for starting the fermentation) for the purpose of improving the quality of the butter was gradually adopted in other dairies and factories, and it was found that at the butter shows an inereasing proportion of the prizes were awarded to those dairies. The report of the scientific investigations was published in 1891. The proportion of dairies and factories which had introduced the method were:

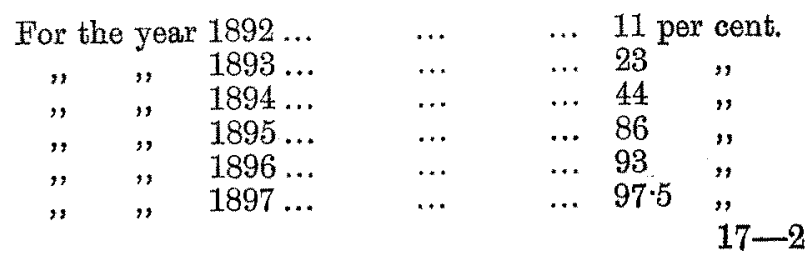


In other words, in the course of six years this new method has become almost universal. Not only that, but at the fortnightly State butter shows in Copenhagen (described in a Foreign Office Report) it was found that the butter from the dairies in which the cream was not pasteurized was very much inferior in quality to that from other dairies, a result which corresponded to the awards given by butter shows held by agricultural societies.

The temperature at first recommended for pasteurizing cream was $160^{\circ} \mathrm{F}$. Experience has gradually led to the use of higher temperatures. At a series of yearly local butter shows at which about 170 dairies exhibited, each manager communicated the temperature to which he heated the cream. The averages of these temperatures show a yearly increase, viz. :

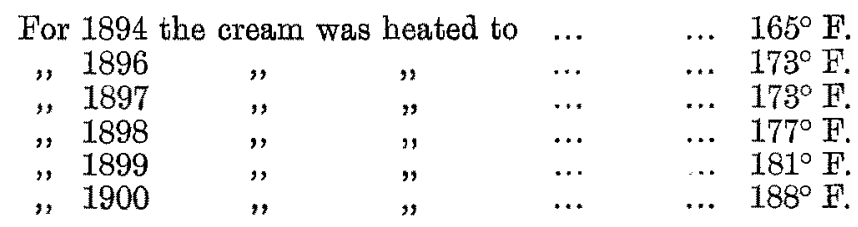

and it was found that the average temperatures for the prize butters were every year higher than those given above.

\section{III.}

The practice of heating the separated milk to $190^{\circ}$ to $195^{\circ} \mathrm{F}$. in order to make it keep sweet, and of heating cream to $180^{\circ} \mathrm{F}$. or beyond in order to insure a superior quality of butter, had been voluntarily adopted by most dairies and dairy-factories by the end of the nineties, quite independently of all prophylactic considerations; when cream is heated to a temperature at which the tubercle bacilli are destroyed, then the butter made from the cream and the butter-milk remaining are equally disinfected. Evidently, then, it would be no hardship to require that all factories should heat their milk and cream in the same way. Steam would have to be provided in those factories which were not yet fitted up with the necessary machinery, and larger boilers would be required in others; but the expense would be a small considera. tion when compared with the advantages gained, viz., protection of the stock against taberculous milk and improved quality of butter. The Legislature was, therefore, easily prevailed upon to insert in a law "for the better protection of cattle from tuberculosis" which obtained the royal assent on March 26th, 1898, the following enactment (Section 6): "Dairies or dairy factories are prohibited from returning as food for cattle milk or butter-milk which 
has not been previously heated to $185^{\circ} \mathrm{F}$." The same Section requires the slime removed from the inside of separators to be burned, as it contains many of the microbes and bacilli from the milk. As milk from cows suffering from tuberculosis of the udder is particularly dangerous, both to calves and to human beings, especially children, the previous Section of the same law provides for the compulsory slaughter of all such cows, with compensation from the State.

In order to give the dairies and factories time to make the necessary addition to their installations, Section 6 of the law of March 26th, 1898, did not come into force till June 1st, 1899. From that time a very effective control has been exercised by the veterinary police and inspectors, under the direction of the Minister of Agriculture. Offences against the law are punishable by fines varying from ten shillings to ten pounds, while insufficiently heated milk is to be confiseated, heated and sold, the proceeds going to the poor fund.

During the first year 1,265 dairies were visited by the veterinary police, each dairy on an average six or seven times, and 8,400 samples of separated milk, and about as many of butter-milk, were taken and sent for testing (see below). In addition to this, a large number of dairies were also visited by the inspectors under the margarine law, who likewise took samples for testing. As might be expected, there were but few dairies in which the milk was not treated as required by the law, and it was found that most offences occurred during the first half year, when deficiencies in machinery and skill had to be made good. During the second half of the year $2 \cdot 2$ per cent. of the samples of separated milk, and $4 \cdot 2$ per cent. of the samples of butter-milk, proved insufficiently heated. That would, in nearly all of these cases, mean that the milk had been heated, but the high degree required by the law had not been reached. With these exceptions, which are certain to materially and speedily decrease in number, it has been brought about by a process of natural development, aided by reasonable legislation, that all milk returned from Danish dairy factories is absolutely free of all suspicion of tuberculosis. The effect of this in protecting calves and pigs fed on this milk it is as yet hardly possible to demonstrate by comparing the percentage of animals attacked before and after the operation of the law; but the result as regards butter is already evident. It is not actually provided in the law that eream must be sterilized, and butter be therefore free from all tubercle bacilli; and the reason for this is plain. The law deals with bovine tubereulosis only, and ealves and pigs are not fed on 
butter. It was, however, for years the habit in most dairies to heat the cream to a high temperature, and the expense of doing so was willingly ineurred because of the improvement in the quality of the butter. When the law now requires the butter-milk to be heated to a certain temperature $\left(185^{\circ} \mathrm{F}\right.$.), it is evidently much easier and cheaper to heat the cream to this temperature than to submit to the following otherwise necessary proceeding-heating the cream for the sake of making good butter, to say $170^{\circ} \mathrm{F}$., cooling it down to $50^{\circ}$ to $60^{\circ}$, and, after the cream has ripened and been churned, heating the sour butter-milk to $185^{\circ} \mathrm{F}$. An effect of the law is, therefore, that all Danish butter, with few and decreasing exceptions, is made from cream from which all suspicion. of tuberculosis has been removed by effectual heating, so that a guarantee of its absolute freedom from any disease germ can be given.

IV.

It remains to answer the question which must have presented itself to the thoughtful reader: How can it be seen or demonstrated on a sample of milk whether it has been sufficiently heated or not? This is, strangely enough, a very simple matter. In the year 1889 Professor Babcock, of Wisconsin, showed that when hydrogen peroxide was added to natural mill it was split up into water and free oxygen, while milk which had been previously boiled had no such effect. Later investigations have proved the presence in milk of an unorganized ferment, or enzyme, to which this reaction is due. This enzyme is destroyed by being heated to a temperature of $176^{\circ} \mathrm{F}$. It is found in all milk, and in the products of milk, viz., cream, separated milk, butter-milk, and whey, so long as these have not been heated to $176^{\circ} \mathrm{F}$. or over; it can even be demonstrated in butter provided this is made from cream which has not been heated to $176^{\circ} \mathrm{F}$. or over. The addition of one drop of a diluted aqueous solution of hydrogen peroxide to a spoonful of fresh milk, will produce free oxygen, and the presence of this can be easily demonstrated by adding a few drops of a solution of one or other of the many chemicals which change colour perceptibly in the presence of free oxygen, preferably potassium iodide and starch or paraphenylendiamin. Two drops of an aqueous solution of the last-named reagent produce in this way a dark indigo-blue colour in milk when it has not been heated above $176^{\circ} \mathrm{F}$. If the milk has been previously heated, no change of colour takes place when one drop of hydrogen peroxide and two drops of paraphenylendiamin are added. Supplied with a small 
bottle of each of these reagents and a small test-tube, all of which can be had for a few pence, anybody can in a few minutes tell whether milk has been heated to the named temperature or not.

It will be noticed that there is a discrepancy between the temperature considered absolutely fatal to tubercle bacilli even by momentary heating, and therefore stipulated in the law in question, viz., $185^{\circ} \mathrm{F}$. , and the temperature at which milk loses its effect to produce the colour reaction described. In practical dairy - work it would, however, be impossible to maintain the temperature of the 'pasteurizer' without oscillations. If it must never be below $176^{\circ}$, it will be necessary to keep it on an average considerably above, that the required temperature may be reached. If only one-tenth of the milk or cream has passed through the heater at $172^{\circ}$, it will reveal itself by the colour reaction, and one part of milk which has reached only $166^{\circ}$ or less is sufficient when mixed with ninety-nine parts of milk heated to $185^{\circ}$ to produce the colour reaction when the mixture is tested: The Legislature relied on this chemical test when they passed Section 6 of this law; without the test the section might be a dead-letter.

It has been mentioned that even butter will react to the colour test. When butter is carefully melted at as low a temperature as possible the milky parts separate out below. When a drop of hydrogen peroxide and two drops of paraphenylendiamin are added to the milky liquid from freshly-made butter, it will turn blue if the cream from which the butter has been made has not been heated to $176^{\circ}$ or above. If the cream has been so heated it is certain that the colour reaction will not be produced. It is equally certain that if the blue colour be produced, the butter was made from cream not heated to $176^{\circ}$. But the absence of the colour reaction is no certain proof of heating, as the enzyme dies away in time, especially when the butter is kept in warm weather. As Danish butter is all made from cream pasteurized at a high temperature, it does not give this colour reaction. When the colour reaction is produced in a sample of butter, it is, therefore, a strong indication that the butter is not Danish, a peculiar instance of the possibility, by means of a simple colour reaction, of testing the nationality. A large number of samples of butter from many different countries have proved the correctness of this statement.

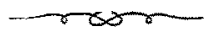

